\title{
Before and after assessment of a sexuality workshop in high-school students
}

\author{
Alfredo Eymann, M.D. ${ }^{a}$, Ferney Baquero, M.D. ${ }^{a}$, María M. Bellomo, M.D. ${ }^{a}$, \\ Julio Busaniche, M.D. ${ }^{a}$, Ignacio Usandivaras, B.S. ${ }^{b}$, Cristina Catsicaris, M.D. ${ }^{a}$ \\ and Valeria Mulli, M.D. ${ }^{a}$
}

\begin{abstract}
Objective. To assess different aspects of the perception of sexuality among students before and after a workshop.

Populationandmethods. Descriptive, qualitative, and quantitative before and after intervention study without a control group. School year, status in relation to sexuality, preferred sources of information, and perception of self-care in relation to sexuality care were analyzed.

Results. A total of 272 surveys were completed before the workshop and 259, after the workshop. The perception about a better level of information increased $(72.3 \%$ versus $90.7 \%)$, and doubts, fears, and embarrassment decreased. The preference for the workshop as an information source increased $(49.1 \%$ versus $69.9 \%$ ), and an improvement was observed in the perception of a correct use of condoms (66.8\% versus $81.1 \%$ ), birth control pills (20.3\% versus $42.5 \%$ ), and emergency contraception (18.5\% versus $40.9 \%$ ). Conclusion. Students' information and perception of self-care in relation to sexuality increased.
\end{abstract}

Key words: workshop, sexuality, adolescent, highschool students.

http: / / dx.doi.org/10.5546/ aap.2019.eng.e477

To cite: Eymann A, Baquero F, Bellomo MM, Busaniche J, et al. Before and after assessment of a sexuality workshop in high-school students. Arch Argent Pediatr 2019;117(5):e477-e484.

a. Department of Clinical Pediatrics.

b. Department of Pediatric Mental Health.

Hospital Italiano de Buenos Aires, Autonomous City of Buenos Aires, Argentina.

E-mail address: Alfredo Eymann, M.D.: alfredo.eymann@hiba. org.ar.

\section{Funding:}

None.

\section{Conflict of interest:} None.

Received: 9-8-2018 Accepted: 4-10-2019 historical, religious, and spiritual factors. ${ }^{1}$ Adolescence is a stage of growth and development full of biological, psychological, and social changes, accompanied by sexual maturation. ${ }^{2}$ Many times, biological maturity is not simultaneous with cognitive and emotional maturity. This period of life is characterized by minimal disease occurrence and maximal vulnerability to risk situations. Therefore, many preventive actions will have a positive impact on adult health. ${ }^{1,2}$

There is consensus on the importance of sexual health promotion and prevention actions developed in the setting of visits to health care providers and at school. After 2006, with the enactment of Law N. ${ }^{\circ} 26150$ for Comprehensive Sex Education (CSE), ${ }^{3}$ efforts were made in the health and education sectors to conduct specific interventions in relation to sexual health care. It has been proposed that sexuality workshops should include the development of knowledge and skills to get to know and care for your own body, and the assessment of emotions and feelings in interpersonal relationships. Therefore, assuming a comprehensive approach to sex education calls for a task aimed at promoting learning from a cognitive and emotional perspective and specific practices related to life in society. ${ }^{4-6}$

The new health education strategies have taken a turn to replace vertical designs -which prioritize specialized knowledge provided to adolescents as passive recipients- with programs that include coordinated efforts and the participation of youth, which are in line with the "open knowledge" model. One of 
these models includes workshops based on the acquisition of life skills. ${ }^{7,8}$

The constituent components of workshops are group work, which favors the incorporation of personal experiences, and stimulation for selflearning. ${ }^{9}$

In the school setting, workshops may facilitate the empowerment of adolescents on different topics and strengthen their autonomy and acquisition of social life skills, as well as critical thinking, emotional control, problem solving, and empathy. ${ }^{10}$ This task raises awareness about the responsibility adolescents should assume in the exercise of their sexuality, generating a space where they can freely express their ideas and perceptions of this topic, either negative or positive. ${ }^{10}$

\section{OBJECTIVE}

To assess some aspects of the perception of sexuality among students before and after a workshop.

\section{POPULATION AND METHODS}

This was a descriptive, qualitative, and quantitative before and after intervention study without a control group. The population was made up of all first through fifth year students attending a non-denominational private high school in the Autonomous City of Buenos Aires.

A survey was developed based on a bibliographic review by a committee of experts on adolescence made up of 3 physicians and 2 psychologists. An apparent validity test was performed in a sample of 7 students, which led to adjustments. No reliability tests were done. The survey was administered upon obtaining the oral consent, individually and anonymously, before and immediately after taking the sexuality workshop during the Spring of 2014 (see Annex).

The activity was coordinated between the school and the health care team through an institutional agreement. Each workshop was designed based on problematic situations observed in each specific group and on the activities performed in the setting of the curriculum design in relation to a comprehensive sexuality. In addition, a teacher was present during workshops so that she/he would be able to work on the proposed issues throughout the school year.

Intervention: the workshop consisted in a 3-hour meeting in the classroom, during school hours. Each workshop was coordinated by
2 health care providers experienced in group work (a physician and a psychologist). The workshop strategy varied for each school year; audiovisual triggers, like short films or film excerpts, were used. As a method of processing, exchange, and reflection, myth versus reality games, role playing, and debates based on opposite sides were performed. To close the workshop, adolescents designed posters and acted out scenes including messages targeted at other adolescents to promote self-care in relation to sexuality.

The following dependent outcome measures were analyzed: sex (female, male), school year (first through fifth), status in relation to sexuality (informed, very embarrassed, hesitant, fearful, under pressure, likely to talk about it with friends and adults), preferred sources of information about sexuality (teachers in class, workshops, brochures, videos, a health care provider at an individual visit, and recreational settings), perception of self-care management in relation to sexuality (making my own decisions, using condoms, using birth control pills, using emergency contraception, knowing the consequences of sexual intercourse without taking precautions, and taking care of myself and/or my partner).

Open questions were made to explore on the resources and strengths or weaknesses to manage information about self-care in relation to sexuality.

Categorical outcome measures were expressed in absolute numbers and percentage. For the qualitative analysis, 2 health care providers defined categories until saturation was achieved in an independent manner. To analyze the change across school years, a $\chi^{2}$ test for the trend was used before the workshop; and to analyze the change before and after the workshop, the McNemar test was done. A value of $p<0.05$ was considered significant. The Stata 8.0 software (Stata Corporation, Texas, USA) was used.

The study was approved by the Ethics Committee for Research Protocols of our site and the education authorities of the participating high school.

\section{RESULTS}

A workshop was carried out in each of the 2 classes for each school year, completing 10 workshops. In total, 272 pre-workshop surveys and 259 post-workshop surveys were obtained, corresponding to students from first through 
fifth year. Thirteen post-workshop surveys were excluded because they were incomplete.

The total number of students per year was 62 , $60,51,49$, and 50 from first through fifth year, respectively; $62.9 \%, 56.7 \%, 43.1 \%, 51 \%$, and $52 \%$ were girls, also respectively.

When comparing how they felt in relation to sexuality before and after the workshop, significant differences were observed in the "informed", "very embarrassed", "hesitant", "fearful", and "likely to talk about it with friends and adults" outcome measures (Table 1).

In relation to the preferred sources of information about sexuality, significant differences were observed before and after the workshop in the following outcome measures: "teachers in class", "workshops", "videos", "a health care provider at an individual visit", and "recreational settings" (Table 2).
In relation to the management of information about sexuality, significant differences were observed when comparing the following outcome measures before and after the workshop: "condom use", "birth control pill use", "emergency contraception use", and "care of myself and/or my partner" (Table 3).

When comparing the perception of adolescents by school year before the workshop, the topic of sexuality, preferred sources of information, and the management of information about sexuality varied in a statistically significant manner as the school year advanced (Figures 1, 2, and 3, respectively).

In the qualitative analysis, the strengths or resources were grouped into the following categories: having information, knowing about correct condom and birth control pill use, the

TABLE 1. Perception of sexuality among students before and after the workshop

\begin{tabular}{lccc}
\hline In relation to sexuality, I feel... & Pre-workshop (\%) & Post-workshop (\%) & ${ }^{*} \boldsymbol{p}$ value \\
\hline Informed & 72.3 & 90.7 & 3.9 \\
Very embarrassed & 8.1 & 8.1 & 0.00001 \\
Hesitant & 20.3 & 7.3 & 0.07 \\
Fearful & 11.1 & 1.5 & 0.00001 \\
Under pressure & 1.8 & 69.5 & 0.5 \\
Likely to talk about it with friends & 65.7 & 54.4 & 0.01 \\
Likely to talk about it with adults & 43.5 & $<.00001$ \\
\hline
\end{tabular}

n pre-workshop: 272; n post-workshop: 259.

* McNemar test.

TABLE 2. Preferred sources of information about sexuality among students before and after the workshop

\begin{tabular}{lccc}
\hline In relation to sexuality, I like hearing/reading about it from... & Pre-workshop (\%) & Post-workshop (\%) & ${ }^{*} \boldsymbol{p}$ value \\
\hline Teachers in class & 28.8 & 37.8 & 0.0008 \\
Workshops & 49.1 & 69.9 & $<0.00001$ \\
Brochures & 13.7 & 15.8 & 0.4 \\
Videos & 22.5 & 34.7 & $<0.00001$ \\
A health care provider at an individual visit & 30.6 & 39.4 & 0.003 \\
Recreational settings (concert, beach, club, etc.) & 24 & 32 & 0.002 \\
\hline
\end{tabular}

n pre-workshop: 272; n post-workshop: 259.

* McNemar test.

TABLE 3. Perception of the management of information about sexuality among students before and after the workshop

\begin{tabular}{lccc}
\hline $\begin{array}{l}\text { I feel that I manage information about sexuality } \\
\text { well enough to take care of myself in relation to... }\end{array}$ & Pre-workshop (\%) & Post-workshop (\%) & ${ }^{*} p$ value \\
\hline Making my own decisions about my sexuality & 61.6 & 64.9 & 0.3 \\
Using condoms & 66.8 & 81.1 & $<0.00001$ \\
Using birth control pills & 20.3 & 42.5 & $<0.00001$ \\
Using emergency contraception & 18.5 & 40.9 & $<0.00001$ \\
Knowing the consequences of sexual intercourse & & 69.1 & 0.009 \\
without taking precautions & 62 & 73.4 & 0.0001 \\
Taking care of myself and / or my partner & 61.3 & & \\
\hline
\end{tabular}

n pre-workshop: 272 ; n post-workshop: 259.

${ }^{*}$ McNemar test.

${ }^{*} p$ value $<0.05 ;{ }^{* *}$ not significant $p$ value. 
Figure 1. Perception of sexuality by school year before the workshop
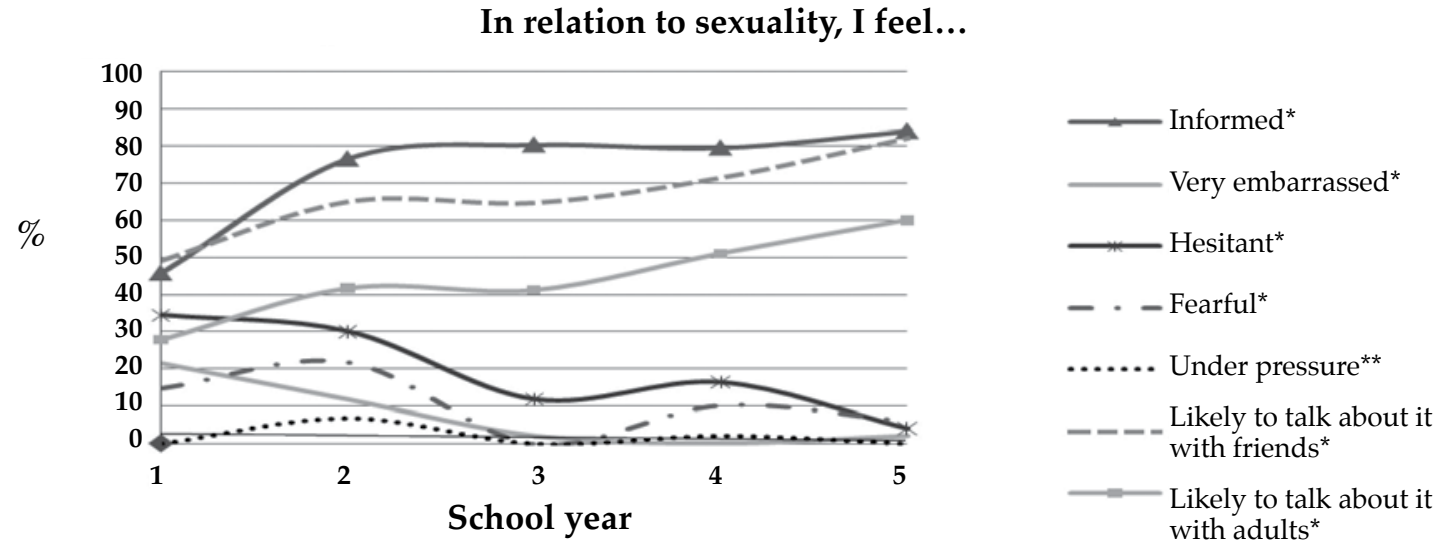

${ }^{*} p$ value $<0.05 ;{ }^{* *}$ not significant $p$ value.

FIGURE 2. Preferred sources of information about sexuality by school year before the workshop

In relation to sexuality, I like hearing/reading about it from...
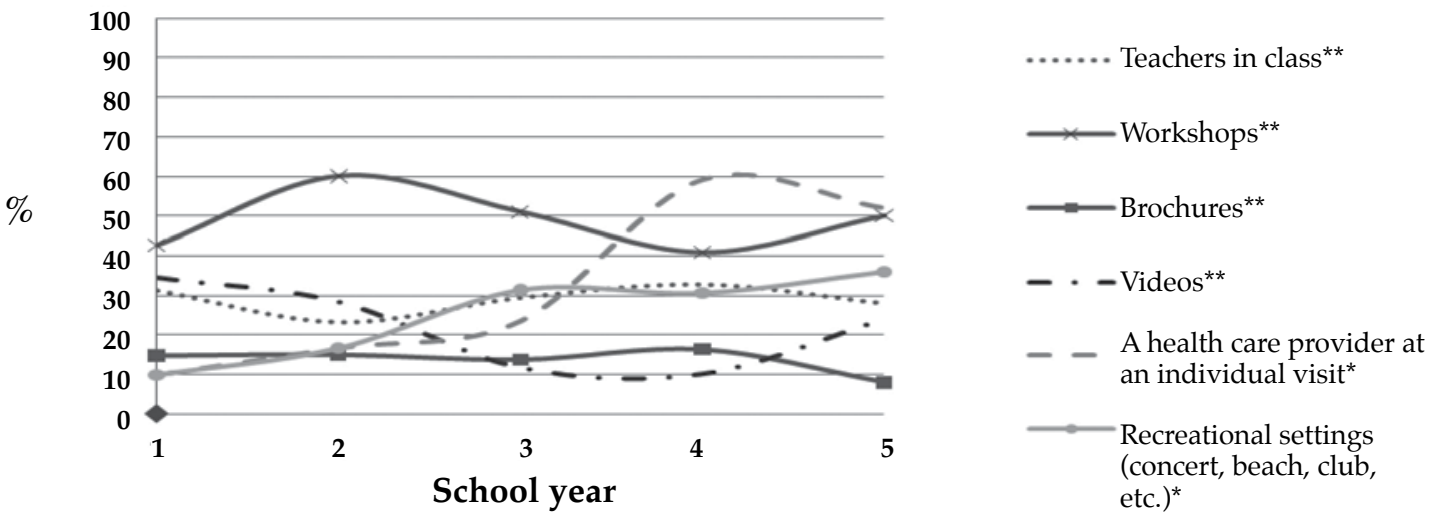

${ }^{*} p$ value $<0.05 ;{ }^{* *}$ not significant $p$ value.

FIGURE 3. Perception of the management of information about sexuality by school year before the workshop


${ }^{*} p$ value $<0.05 ;{ }^{* *}$ not significant $p$ value. 
possibility of talking to friends and family, and making the right decisions themselves.

In the pre-workshop survey, students stated the following in relation to their strengths regarding sexuality: "willingness to use contraceptives", "trusting my boyfriend and supporting each other when in trouble", "ability to calm down and think in very compromising situations", "thinking things for myself", and "having friends who are going to help me". From the post-workshop survey, it was worth noting the following statements: "I feel more confident, the activity was really helpful", "I can take the condoms myself, I'm not ashamed", "I'm open to ask what I don't know", "I have my friends and I can talk to them more now", "I know much more about it, before I didn't even know how to put on a condom", "I can talk without inhibitions", "I can say stop, stop it here", and "I have enough information to discuss whether I want to do it or not".

Weaknesses were grouped into the following categories: lack of information, fears to both sexually transmitted diseases and pregnancy, not being able to talk to their family, lack of selfcontrol, and lack of experience.

In the pre-workshop survey, students stated the following: "not being sober or in a normal state", "my family does not support me", "being shy, keeping my doubts to myself and then they end up being important", "not being able to take the pills because my mom doesn't know and I don't want to tell her", "I need to talk about it more", "it's embarrassing", and "I'd be scared; after all, it's us girls who get pregnant". From the post-workshop survey, it was worth noting the following statements: "I'm scared of pregnancy", "I have doubts about my sexual preferences", "I'm scared of getting a disease, like AIDS", "after the workshop, I'm not as scared as before", and "I don't have all the information, but I can ask".

\section{DISCUSSION}

The results of our study have demonstrated that workshops were a valid device in the school setting to approach sexuality issues during adolescence. The work dynamics used here may help to put students in a dilemma that is similar to what they may experience themselves and, thus, propose alternative resolutions through the development of social life skills. Workshops have been described as an instrument designed to bridge the gap between the population and the health system so that those involved may question their knowledge about their bodies, sexuality, and self-care practices and, finally, turn these workshops into an opportunity for the collective development of knowledge. ${ }^{4-6}$

Some authors have analyzed, using before and after designs, the impact of preventive activities in the setting of a workshop aimed at adolescents, and results have been successful. Rebullet al. ${ }^{11}$ carried out a study in Tarragona (Spain) that included a single session workshop with adolescents attending fourth year of high school aimed at reducing the risk for transmission of human immunodeficiency virus (HIV) and increase knowledge about this condition. When they administered a questionnaire 6 months after the workshop, they found a statistically significant increase in the number of correct answers in the items related to HIV general knowledge and prevention.

In our study, we verified that, before the workshop, in the higher high school years, adolescents felt better informed and less fearful and hesitant in relation to sexuality. This may be because, on the one side, they were older and more mature and, on the other side, they had participated in previous workshops as part of the school's institutional education project. After the workshop, a significant increase in the perception about a better information level, a greater likelihood to talk about sexuality with adults, and a significant reduction in terms of doubts, fears, and embarrassment were observed.

It was noticed that, before the workshop, almost half of the students preferred this type of activity over other sources of information about sexuality. Those in the higher school years also felt comfortable talking about it with a health care provider or in a recreational setting. After the workshop, almost a third of all the students in the high school preferred this method. The increase was significantly more important compared to other sources, probably because workshops provide a greater possibility for active participation and open development of knowledge or due to the bias of having participated in the workshop immediately before completing the assessment. In this case, it is also striking that there was no significant difference before and after the workshop in terms of the use of brochures as a source of information, which leads us to consider that they may not be useful in this type of population unless they were accompanied with thoughtful considerations. 
Before the workshop, a significant tendency was observed: in the higher school years, adolescents stated that they felt better informed about condom use and more capable of making decisions by themselves in relation to their sexuality. After the activity, an encouraging increase was observed in the perception of knowing how to correctly use condoms and also in the knowledge about the correct use of other contraceptive methods, such as birth control pills and emergency contraception. However, no statistically significant difference was observed in the ability to make decisions for themselves, which was considered to be because this type of changes could not be assessed after exposure to a single intervention but, on the contrary, because it required maintenance over time, including coordinated tasks among the family, the school, and health care staff, as proposed in the study by Gosende et al. ${ }^{12}$

One of the limitations of this study is that it was conducted in a group of adolescents attending a non-denominational, urban private school, so the results cannot be generalized and extrapolated to other types of populations, like students attending public or religious schools or adolescents who are not even attending school.

In addition, a potential bias of the design of before and after studies is that there is no control group so it is complex to establish whether results may be affected by the acquisition of information from other sources or different interventions. In order to control such bias, we decided to administer the post-workshop survey immediately after the activity ended. However, it is clear that, this way, it is also possible to fall in the bias of trying to please survey respondents with the experience lived during the workshop and lead them to opt for this device.

Rubio et al. ${ }^{13}$ conducted a study to assess the impact of workshops on sexuality in first- and third-year adolescents attending a high school in San Cristóbal, Venezuela. They administered preand post-workshop questionnaires, immediately after finishing the activity and 3 months later, and concluded that, after such period, participants maintained acquired knowledge. Therefore, it is important to carry out further studies to assess the acceptance of workshops and acquired knowledge both at the end of the activity and over time, and to check their validity.

The analysis of the qualitative aspects of this study shows certain lack of consistency among many surveys that mentioned that information as a resource and, at the same time, a lack of information as a weakness. Such finding may also be because participants had just acquired the new information but also considered it to be still insufficient.

It is worth noting that the quotes included here were selected by the authors because they were considered a constitutive description of the categories included in the qualitative analysis. The use of intentional sampling does not pretend to generalize results but to understand certain specific cases, as described by Ruiz Olabuenaga. ${ }^{14}$

Although it is difficult to measure behavioral changes in terms of adolescent sexuality, the workshop strategy has demonstrated to be effective, so the concept of self-managementtypical of this group dynamics-and the social skill approach facilitate the empowering process and allow integrating cognitive, relationship, emotional, and cultural variables in adolescents. 15,16

The assessment of this type of prevention intervention is highly intricate and requires further studies to grasp its scope. ${ }^{12}$

\section{CONCLUSION}

Students' information and perception of self-care management in relation to sexuality increased. The workshop was a useful device to approach sexuality with adolescents in the school setting.

\section{REFERENCES}

1. World Health Organization. Defining sexual health. Report of a technical consultation on sexual health 28-31 January 2002. Ginebra: WHO; 2006. [Accessed on: April 11 ${ }^{\text {th }}, 2019$ ]. Available at: https: / / www.who.int/ reproductivehealth / publications / sexual_health/defining_sexual_health.pdf.

2. McAnarney ER, Kreipe ER, Orr DP, Comerci GD. Medicina del Adolescente. Buenos Aires: Panamericana; 1994.

3. Ley 26150. Programa Nacional de Educación Sexual Integral. BoletínOficial de La República Argentina. Buenos Aires, Argentina. 23 de octubre de 2006.

4. Argentina. Ministerio de Salud de la Nación, Programa nacional de salud sexual y procreación responsable, Programa SUMAR. Experiencias para armar: Manual para talleres en salud sexual y reproductiva. 2014. [Accessed on: April 11 $\left.{ }^{\text {th }}, 2019\right]$. Available at: http://www.codajic. org/sites/www.codajic.org/files/Manual_experiencias_ para_armar.pdf

5. Argentina. Ministerio deeducación de la nación. Programa nacional de educación sexual integral (ESI). [Accessed on: April11 ${ }^{\text {th }}$, 2019]. Available at: https: / / www.argentina.gob. ar/educacion/esi.

6. Argentina. Programa nacional de prevención delembarazo no intencional en la adolescencia. Materialeseducativos. [Accessed on: April 11 ${ }^{\text {th }}, 2019$ ]. Available at: https: / / www. argentina.gob.ar/planenia/ recursos.

7. Schutt-Aine J, Maddaleno M. Salud sexual y desarrollo de 
adolescentes y jóvenes en las Américas: Implicaciones en programas y políticas. Washington, DC: OPS; 2003. [Accessed on: April 11 $\left.{ }^{\text {th }}, 2019\right]$. Available at: http:/ / saludxmi. cnpss.gob.mx/inpsiquiatria/portal/saludxmi/bibliote$\mathrm{ca} /$ sexuality /m3_Factores_desarrollo_saludsexual_adolescentes.pdf.

8. World Health Organization. Life Skills Education for Children and Adolescents in Schools. Programme on Mental Health. Ginebra: WHO; 1993.

9. García D. Innovaciones pedagógicas. In El grupo. Métodos y técnicasparticipativas. Buenos Aires: Espacio editorial;2001. Págs.17-46.

10. Vásquez ML, Argote LA, Castillo E, Mejía ME, et al. Educación en derechos sexuales y reproductivos: una perspectiva integral con adolescentes escolarizados. Colomb Med. 2005; 36 (Supl 2): 6-13.

11. RebullFatsini J, RevertéSimó M, Piñas Forcadell I, OrtíLlavería A, et al. Evaluación pre-post de una actividad preventiva de la infección por VIH dirigida a los adolescentes de las comarcas del sur de Tarragona. Rev Esp Salud Pública. 2003; 77(3):373-82.
12. Gosende E, Ferreyra M, Scarimbolo G. Talleres de género y educación sexual para adolescentes de escuelas secundarias: la crisis dentro de la crisis o el desafío de ofrecer vínculos de cuidado en instituciones estalladas. IV Congreso Internacional de Investigación y Práctica Profesional en Psicología. XIX Jornadas de Investigación. VIII Encuentro de Investigadores en Psicología del MERCOSUR. Universidad de Buenos Aires, facultad de psicología. 2012. [Accessedon: April 11 $\left.{ }^{\text {th }}, 2019\right]$. Available at: https://www. aacademica.org/000-072/454.pdf.

13. Rubio I, Granadlllo D, Salinas PJ. Técnicas participativas en la educación sexual y cambios de conducta en adolescentes. Rev Fac Med Univ de los Andes. 1999; 5(1-4): 24-31.

14. Ruiz Olabuenaga JI. Metodología de la investigación cualitativa. Bilbao: Universidad de Deusto; 1999.

15. Soto M, Oliver M. ¡Órdago! Evaluación de la aplicación en la Comunidad Valenciana. Bilbao: Edex; 2003.

16. Melero JC. Osasunkume. La aventura de la vida. Evaluación de resultados. Bilbao: Edex; 2003. 


\section{ANNEX. \\ Sexuality Workshop Survey}

Hello, please complete this anonymous survey to find out about your perceptions in relation to sexuality.

Thank you.

Sex: $\quad$ Female. $\quad$ Male.

In relation to sexuality, I feel...

(You may select more than one answer).
- Informed.
- Likely to talk about it with friends.
- Very embarrassed.
- Hesitant.
- Likely to talk about it with adults.
- Under pressure.

- Fearful.

In relation to sexuality, I like hearing/reading about it from...

(You may select more than one answer).

- Teachers in class.

- Videos.

- Recreational settings.
- Workshops.

- A health care provider at an individual visit.
- Brochures.

In relation to what topics of sexuality do I feel that I manage information well enough to take care of myself?

(You may select more than one answer).

- Making my own decisions.

- Using condoms.

- Using birth control pills.

- Using emergency contraception.

- Knowing the consequences of sexual intercourse without taking precautions.

- Taking care of myself and/or my partner.

What do you think are your strengths regarding self-care in relation sexuality?

What do you think are your weaknesses regarding self-care in relation sexuality? 